\title{
87. Deciduoma Formation in Adult Rats Treated Neonatally with Estradiol Benzoate, 5a-Dihydrotestosterone Benzoate or Combination of the Two
}

By Yasuhiko OHTA*) and Kiyoshi TakewakI, M. J. A.

(Communicated June 8, 1976)

Female rats given a single sc injection of $1,250 \mu \mathrm{g} 5 \alpha$-dihydrotestosterone (DHT) or its propionate (DHTP) on day 5 of postnatal life were ovariectomized at about 60 days of age and given 7 daily combined injections of $2,000 \mu \mathrm{g}$ progesterone (P) and $0.2 \mu \mathrm{g}$ estradiol-17 $\beta$ (ED). Uterine trauma applied on the 4th day of the injections always resulted in well developed deciduomata by the day after the last injection (Takewaki and Ohta, 1975). This made a sharp contrast to the failure of females receiving testosterone propionate (TP) neonatally to give a positive response under similar experimental conditions (Takewaki and Ohta, 1974).

The present paper deals with the effects of neonatal treatment with estradiol benzoate (EB), $5 \alpha$-dihydrotestosterone benzoate (DHTB) or the combination of the two steroids on response to uterine traumatization in adulthood.

Materials and methods. On day 5 of postnatal life (day $1=$ day of birth), female $\mathrm{T}$ rats received a single sc injection of $60 \mu \mathrm{g} \mathrm{EB}$ (Sigma) (Group I, n=9), 1,000 $\mu \mathrm{g}$ DHTB (Sigma) (Group II, $\mathrm{n}=10$ ) or the two steroids in combination (Group III, $n=9$ ). Seven other animals given no neonatal steroid treatment served as controls (Group IV). Daily doses were dissolved in $0.04 \mathrm{ml}$ sesame oil in Groups I and II, and in $0.08 \mathrm{ml}$ in Group III. The pups were weaned on about day 22.

When the rats were approximately 50 days old, daily vaginal smears were taken from each animal. The Group II rats showed regular 4-day cycles like Group IV controls, while the other two groups of animals exhibited persistent vaginal cornification.

On about day 60 , both ovaries were removed from each animal. Cycling rats were ovariectomized on the day of estrus. The ovaries were weighed, examined macroscopically for the presence of corpora lutea and fixed in Bouin's fluid for histological studies.

Commencing on the day following ovariectomy, all rats were given sc injections of $2,000 \mu \mathrm{g}$ P plus $0.2 \mu \mathrm{g}$ ED in $0.15 \mathrm{ml}$ sesame

*) Department of Biology, Kawasaki Medical College, Kurashiki, Okayama 701-01, Japan. 
Teble I. Deciduoma formation in response to uterine trauma in rats treated neonatally with EB, DHTB or EB+DHTB

\begin{tabular}{rlccc}
\hline \multirow{2}{*}{ Group } & $\begin{array}{c}\text { Positive } \\
\text { response }\end{array}$ & \multicolumn{2}{c}{ Weight (M. \pm S. E. mg) of } \\
\cline { 3 - 4 } & & $5 / 9$ & $\begin{array}{c}255.8 \pm 102.7^{*} \\
\text { traumatized horns }\end{array}$ & intact horns \\
\hline I & $60 \mu \mathrm{g} \mathrm{EB}$ & $113.8 \pm 1.0)^{* *}$ & $83.6 \pm 4.9$ \\
II & $1,000 \mu \mathrm{g} \mathrm{DHTB}$ & $10 / 10$ & $678.2 \pm 37.4$ & $105.6 \pm 5.4$ \\
III & $60 \mu \mathrm{g} \mathrm{EB}+$ & $1 / 9$ & $(118.8 \pm 5.9)$ & $86.5 \pm 5.1$ \\
& $1,000 \mu \mathrm{g} \mathrm{DHTB}$ & $7 / 7$ & $693.3 \pm 106.3$ & $123.6 \pm 4.6$ \\
IV & (control) & &
\end{tabular}

EB estradiol benzoate; DHTB $5 x$-dihydrotestosterone benzoate.

* If a rat showir $g$ exceptionally large deciduomata is excluded, this value is reduced to $154.2 \pm 20.1$.

** Weights of traumatized horns without deciduomata are given in parentheses.

oil for 7 consecutive days. On the fourth day of the injection period, the antimesometrial surface of endometrium of the right uterine horn of each animal was scratched longitudinally along the entire length by a hooked needle inserted into its lumen (Takewaki, 1969). The contralateral horn was left intact. On the day following the last $\mathrm{P}-\mathrm{ED}$ injection, all rats were killed. After their uteri were inspected for gross evidence of deciduomata, traumatized and intact horns were trimmed of extraneous tissues, weighed separately and fixed for histological processing.

Data were analyzed using Student's $t$ test. Differences between means at the $\mathrm{p}<0.05$ level were considered significant.

Results and discussion. The ovaries removed around day 60 from the rats of Groups I and III were significantly smaller in mean weight $(26.9 \pm 2.4 \mathrm{mg}$ and $31.7 \pm 2.3 \mathrm{mg}$, respectively) than those from Group IV controls $(81.3 \pm 3.3 \mathrm{mg})$, while those from the animals of Group II were not significantly different from the control ovaries, weighing $76.9 \pm 2.8 \mathrm{mg}$ on an average. The ovaries from the rats of Groups I and III were polyfollicular and lacked corpora lutea, in contrast to those from the other two groups invariably containing some corpora lutea. This is in agreement with the concept that nonaromatizable androgens administered to neonatal female rats are ineffective in inducing masculinization of the hypothalamic control mechanism of gonadotropin secretion (For literature, see Takewaki and Ohta, 1975).

As shown in Table I, all Group II animals formed well developed deciduomata in response to uterine trauma as previously observed in those treated neonatally with DHT or DHTP (instead of DHTB) (Takewaki and Ohta, 1975). The traumatized horns of Group II 
rats were approximately the same in mean weight as those of Group IV controls.

Five of the 9 Group I rats given EB neonatally formed deciduomata. In 4 of the 5 rats, however, deciduomata were small and nodular, traumatized horns of the 4 rats averaging $154.2 \pm 20.1 \mathrm{mg}$ in weight. The traumatized horn of the 5th rat was exceptionally large, weighing $662 \mathrm{mg}$. In Group III, only 1 of the 9 rats responded to uterine trauma by formation of a deciduomal nodule. The traumatized horn of this rat weighed $154 \mathrm{mg}$. The rest of the animals totally failed to react to uterine trauma. It is evident that the uterus was strongly affected by neonatal administration of $60 \mu \mathrm{g} \mathrm{EB}$ and that as much as $1,000 \mu \mathrm{g}$ DHTB given simultaneously failed to annihilate the effect of EB.

\section{References}

Takewaki, K. (1969) : Annot. Zool. Japon., 42, 126.

Takewaki, K., and Y. Ohta (1974) : Endocrinol. Japon., 21, 343.

—_ (1975) : ibid., 22, 561. 